\title{
AGE \& SEX DETERMINATION OF FOETUS FROM ILIUM: A MEDICOLEGAL ASPECT
}

\author{
Jaswinder Kaur¹, Monika Gupta², Parmod Kumar Goyal ${ }^{3}$
}

\section{HOW TO CITE THIS ARTICLE:}

Jaswinder Kaur, Monika Gupta, Parmod Kumar Goyal. "Age \& Sex Determination of Foetus from Ilium: A Medicolegal Aspect". Journal of Evolution of Medical and Dental Sciences 2015; Vol. 4, Issue 28, April 06;

Page: 4909-4911, DOI: $10.14260 /$ jemds/2015/714

ABSTRACT: The use of coxal elements for age \& sex diagnosis from the skeleton is the primary \& most widespread way of bringing us closer to the identity of dead individuals in archeological \& certain forensic scenarios. The sample used in this study was obtained from two decomposed bodies which were found in a river near Bathinda. The age \& sex was determined from the measurements of ilium with Vernier Caliper \& morphology of Greater Sciatic Foramen was studied. Depth \& breadth of ilium of $1^{\text {st }}$ case was $25,25 \& 22,21$ and in $2^{\text {nd }}$ case it was $28,28 \& 24,25(\mathrm{~mm})$ on Right \& Left side respectively. The morphology (Shape) of greater sciatic foramen was studied \& the shape was deep in both the foetuses. From the depth $\&$ breadth of ilium the age of $1^{\text {st }}$ case was $32 \mathrm{wks} \&$ that of $2^{\text {ndfoetus }}$ was between 34-38wks. From the greater sciatic foramen the sex of both the foetuses was male.

KEYWORDS: Iliuem, Age, Sex.

INTRODUCTION: The use of coxal elements for age \& sex diagnosis from the skeleton is the primary \& most widespread way of bringing us closer to the identity of dead individuals in archeological \& certain forensic scenarios. ${ }^{1}$ The determination of sex in human skeletal remains is crucial to making conclusions about demography \& cultural trends of past populations. The bony pelvis exhibits sexually distinct features \& is the most accurate indicator of sex for adult specimens. Methods involving the ilium, the largest bone of the pelvis, have demonstrated the most consistent results across multiple tests. ${ }^{2}$

CASE HISTORY: The foetus bodies were handed over to the department of Anatomy for medical education and research by the police officers after post-mortem examination, being conducted by board of doctors at Civil Hospital Bathinda. On arrival at Anatomy department foetal bodies were in advanced stage of putrefaction.

MATERIAL \& METHODS: After cleaning and washing of the bodies with water, skeletal remains got separated easily and then after that recovered bones were dried. The age \& sex was determined from the measurements of ilium with Vernier Caliper \& morphology of Greater Sciatic Foramen was studied.

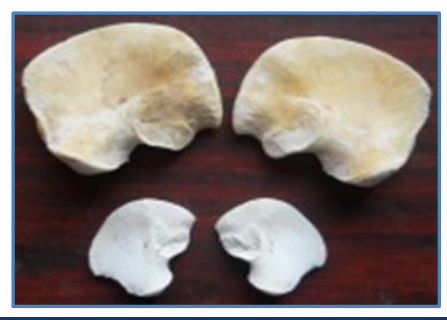

Rt \& Lt Ilium of case-1 \& 2 


\section{CASE REPORT}

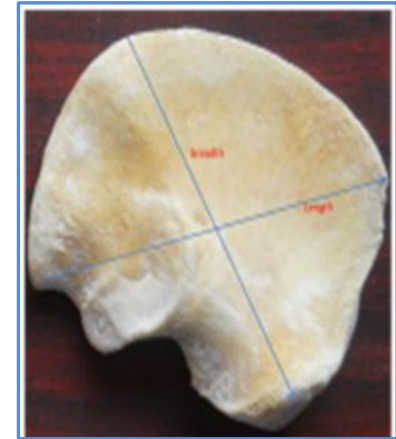

Measurements of Ilium (Length\& Breadth)

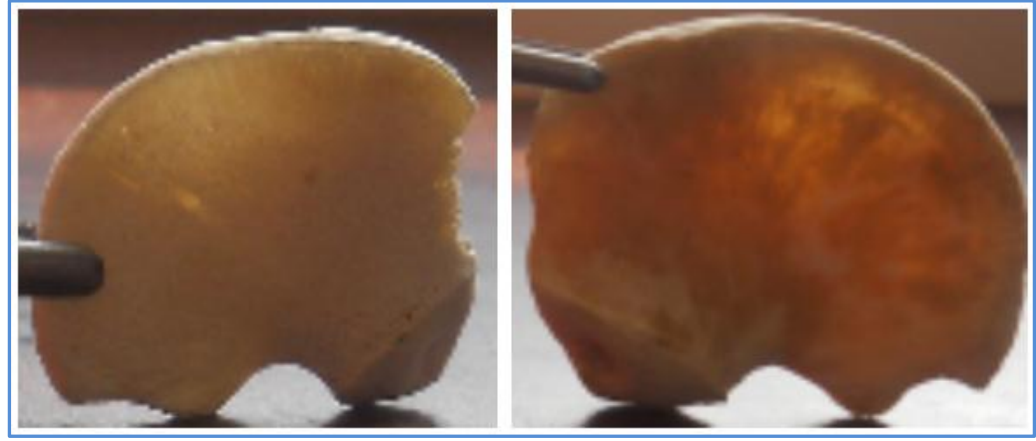

Shape of Greater Sciatic Notch

\section{RESULTS:}

- Length \& breadth of ilium of 1 st case was 25, 25\&22,21and in 2nd Case it was 28, 28\& 24, $25(\mathrm{~mm})$ on Right \& Left side respectively.

- The morphology (Shape) of greater sciatic foramen was studied \& the shape was deep in both the foetuses.

DISCUSSION: The foetal iliac length as studied by other authors by ultrasound was $25.30 \mathrm{~mm}$ at 32 wks of gestational age $\& 38.36$ at 38 wks of gestational age. ${ }^{3}$ In our present study, the length of ilium was $25 \mathrm{~mm}$ in one case $\& 28 \mathrm{~mm}$ in $2^{\text {nd }}$ case that is in relation with past studies. In the morphometry of greater sciatic notch, the bone viewed from dorsal aspect \& the shape of greater sciatic notch was studied which is shallow in females \& deep in males. ${ }^{1}$ in present study, the shape of greater notch was deep in both the cases which indicates that both the cases were male.

CONCLUSION: From the depth \& breadth of ilium the age of 1 st case was 32 wks \& that of $2^{\text {nd }}$ foetus was between 34-38wks. From the greater sciatic foramen the sex of both the foetuses was male.

\section{REFERENCES:}

1. Rissech C \& Malgosa A: Ilium growth study: applicability in sex \& age diagnosis. Forensic science international 2005; 147(2): 165-174.

2. Vlak D, Roksandic M \& Schillaci MA: Greater sciatic notch as a sex indicator in Juveniles. Am J Phys Anth 2008; 137(3): 309-315.

3. Scheuer L \& Black S: Developmental juvenile osteology. In length \& breadth of ilium. Google books pp 373-375. 


\section{AUTHORS:}

1. Jaswinder Kaur

2. Monika Gupta

3. Parmod Kumar Goyal

\section{PARTICULARS OF CONTRIBUTORS:}

1. Professor \& HOD, Department of Anatomy, Adesh Institute of Medical Sciences \& Research, Bathinda, Punjab.

2. Associate Professor, Department of Anatomy, Adesh Institute of Medical Sciences \& Research, Bathinda, Punjab.

FINANCIAL OR OTHER COMPETING INTERESTS: None
3. Professor \& HOD, Department of Forensic Medicine, Adesh Institute of Medical Sciences \& Research, Bathinda, Punjab.

\section{NAME ADDRESS EMAIL ID OF THE CORRESPONDING AUTHOR:}

Dr. Jaswinder Kaur, Professor \& HOD, Department of Anatomy, Adesh Institute of Medical Sciences \& Research, Barnala Road, Bathinda, Punjab-151001.

E-mail: jaswindpreet@gmail.com

Date of Submission: 11/03/2015. Date of Peer Review: 12/03/2015. Date of Acceptance: 25/03/2015. Date of Publishing: 06/04/2015. 